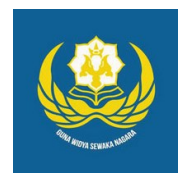

Jurnal Analogi Hukum

Journal Homepage: https://ejournal.warmadewa.ac.id/index.php/analogihukum

\title{
Penyelesaian Sengketa Pembagian Harta Bersama yang Dijadikan Jaminan Hutang Melalui Akta Perdamaian
}

\author{
I Gede Arya Agus Pratama*, Ni Luh Made Mahendrawati dan Luh Putu Suryani \\ Universitas Warmadewa, Denpasar-Bali, Indonesia \\ *aguspratama@gmail.com
}

\begin{abstract}
How To Cite:
Pratama, I, G, A, A., Mahendrawati, N, L, M., Suryani, L, P. (2020). Penyelesaian Sengketa Pembagian Harta Bersama yang Dijadikan Jaminan Hutang Melalui Akta Perdamaian. Jurnal Analogi Hukum, 2 (2). 165-169. Doi: https://doi.org/10.22225/ah.2.2.1915.165-169
\end{abstract}

\begin{abstract}
Joint assets are assets that a husband and wife can obtain during marriage. Dispute resolution means that the resolution of a conflict between two or more parties originating from different perceptions about an interest or property rights that can have legal consequences for both. The Peace Deed is after the parties mediate, a case agreement is reached on the subject matter of the dispute formulated in the peace agreement. At the appointed hearing, the case filed the peace agreement so that it could be used as a peace deed to resolve their dispute. Based on the explanation above, the following issues will be discussed: 1. Can the joint property of the marriage which is used as a debt security to a third party be the object of a peace agreement by the Plaintiff and Defendant? and 2. How is the process of resolving disputes over joint assets that are used as collateral for debts to third parties? This research uses normative legal research methods, using the statutory approach and conceptual approach, assessing primary and secondary legal materials. The results of this study indicate: That, joint property of a marriage that is in the second place as a debt collateral, cannot be used as an object of ownership disputes, or objects in the peace deed between the plaintiff and the defendant without involving the right holder's collateral, Husband or wife husband and wife disputing shared assets that are used as collateral for debt, must place the collateral holder as one of the cases.
\end{abstract}

Keywords: Disputes, joint assets, peace deed

\begin{abstract}
Abstrak - Harta bersama adalah harta yang di dapat suami istri selama perkawinan. Penyelesaian sengketa mempunyai makna bahwa penyelesaian pertentangan antara dua pihak atau lebih yang berawal dari persepsi yang berbeda tentang suatu kepentingan atau hak milik yang dapat menimbulkan akibat hukum bagi keduanya. Akta Perdamaian adalah setelah para pihak melakukan mediasi, tercapai kesepakatan pihak perkara tentang pokok sengketa yang dirumuskan dalam perjanjian perdamaian. Pada sidang yang ditentukan, pihak perkara mengajukan perjanjian perdamaian tersebut agar dijadikan akta perdamaian sebagai penyelesaian sengketa mereka. Berdasarkan uraian di atas akan di bahas permasalahan : 1. Apakah harta bersama perkawinan yang dijadikan jaminan utang pada pihak ketiga dapat menjadi obyek kesepakatan perdamaian oleh Penggugat dan Tergugat ? dan 2.Bagaimana proses penyelesaian sengketa terhadap harta bersama yang dijadikan jaminan utang pada pihak ketiga ?. Penelitian ini menggunakan metode penelitian hukum normatif, menggunakan pendekatan perundang-undangan dan pendekatan konseptual, mengkaji dari bahan hukum primer dan bahan hukum sekunder. Hasil penelitian ini menunjukan bahwa, harta bersama perkawinan yang sedang dalam kedudukan sebagai jaminan utang, tidak dapat dijadikan obyek sengketa kepemilikan, ataupun obyek dalam akta perdamaian antara penggugat dan tergugat tanpa melibatkan pihak pemegang hak jaminan, Suami istri atau bekas suami istri bersengketa terhadap harta bersama yang dijadikan jaminan utang, harus mendudukkan pihak pemegang jaminan sebagai salah satu dari pihak perkara.
\end{abstract}

Kata Kunci: Sengketa, harta bersama, akta perdamaian

\section{Pendahuluan}

Salah satu akibat hukum suatu perkawinan tidak hanya tertuju pada diri suami istri, akan tetapi juga mengenai harta kekayaan yang di miliki oleh kedua suami istri (Hartanto, 2017). Hukum perkawinan di Indonesia, menentukan harta yang diperoleh selama perkawinan tersebut sebagai harta bersama. Perihal harta bersama tersebut diatur dalam Pasal 35 hingga 
37 Undang-undang Nomor 1 Tahun 1974 tentang Perkawinan. Materil hukum perkawinan dalam Peradilan Agama merupakan subtansi dalam pelaksanaan hukum Islam itu sendiri, karena tidaklah mungkin dalam sebuah putusan yang dihasilkan oleh Badan Peradilan Agama tanpa merujuk pada Undang-Undang yang diberlakukan oleh sebuah Negara (Jamil, 2017).

Bilamana terjadi perceraian, undangundang menentukan, bahwa perihal harta bersama diatur menurut hukumnya masingmasing. Adapun yang dimaksud dengan hukumnya masing-masing tersebut adalah ialah hukum agama, hukum adat dan hukum lainnya. Bagi orang yang melakukan perkawinan berdasar hukum Islam, bila kemudian bersengketa tentang harta bersama perkawinan tersebut, peradilannya menjadi kewenangan lembaga peradilan agama, karena sengketa bidang tersebut menjadi bagian dari sengketa bidang perkawinan yang menjadi kewenangan pengadilan agama sebagaimana yang ditentukan oleh Pasal 49 Undang-undang Nomor 7 Tahun 1989 sebagaimana diubah dengan Undangundang Nomor 3 Tahun 2006 dan perubahan yangkedua dengan Undang-undang Nomor 50 Tahun 2009.

Secara umum penyelesaian sengketa dapat di golongkan menjadi dua cara, yaitu pertama penyelesaian sengketa melalui jalur lembaga peradilan (litigasi),dan kedua melalui jalur di luar pengadilan (non-litigasi) (Artadi \& Asmara, 2017). Hukum Acara Perdata menentukan, bahwa saat penggugat dan tergugat hadir dalam sidang, majelis hakim harus mendamaikan pihak tersebut dalam acara perdamaian, dan kemudian berdasarkan ketentuan Perma Nomor 1 Tahun 2016, acara perdamaian tersebut harus diteruskan melalui lembaga mediasi, yang untuk itu ditunjuk seorang mediator untuk melaksanakan proses perdamaian tersebut. Aturan mediasi di atas menentukan, bahwa dalam hal mediasi berhasil mencapai kesepakatan, para pihak dengan dibantu oleh mediator tersebut, dapat menuangkan kesepatan perdamaian tersebut dapat diajukan kepada majelis hakim untuk ditetapkan sebagai Akta Perdamaian, yang mempunyai kekuatan eksekutorial.

Pembagian harta bersama perkawinan, mensyaratkan tentang kejelasan hak kepemilikan dari suami istri terhadap harta dimaksud, sehingga sebuah putusan tentang harta bersama haruslah menyebutkan secara jelas alas hak hukum serta kejelasan tentang penguasaan suami istri atas harta dimaksud. Harta yang kedudukannya sedang berada sebagaijaminan utang, atau harta yang belum sempurna kepemilikannya, seharusnya tidak dapat ditetapkan sebagai obyek sengketa pembagian harta bersama harta bersama, tanpa melibatkan pihak pemegang hak jaminan tersebut. Pemegang hak jaminan adalah kreditor yang kedudukannya diutamakan terhadap harta yang dijadikan jaminan utang, sebagaimana ketentuan pasal 1132 KUH Perdatadan Pasal 1 ayat 1 Undang-undang Nomor 4 Tahun 1996 tentang Hak Tanggungan.

Pengadilan Agama Denpasar telah memutuskan dalam perkara gugatan harta bersama perkawinan, yang pihak penggugat dan tergugatnya berhasil mencapai kesepakatan perdamaian, selanjutnya kesepakatan tersebut dituangkan dalam Akta Perdamaian dengan diberi kekuataneksekutorial dengan irah-irah Demi Keadilan Berdasarkan Ketuhanan Yang Maha Esa, dengan Putusan Nomor 147/ Pdt.G/ 2018/ PA Dps. akan tetapi, dalam akta perdamaian tersebut Majelis hakim tidak mempertimbangkan bahwa harta yang jadi obyek sengketa tersebut adalah harta yang sedang dalam penjaminan utang di bank yang belum lunas. Berdasarkan uraian di atas, penulis bermaksud mengkaji putusan tersebut dalam penelitian ini untuk menelaah tentang prinsip penjaminan terhadap harta bersama perkawinan, serta bagaimana seharusnya penyelesaian sengketa pembagian harta bersama yang dijadikan jaminan utang.

Berdasarkan uraian latar belakang tersebut akan dibahas yaitu:

Apakah harta bersama perkawinan yang dijadikan jaminan utang pada pihak ketiga dapat menjadi obyekkesepakatan perdamaian oleh Penggugat dan Tergugat?

Bagaimana proses penyelesaian sengketa terhadap harta bersama yang dijadikan jaminan utang pada pihak ketiga?

Penelitian ini bertujuan untuk:

Untuk mengetahui harta bersama perkawinan yang dijadikan jaminan utang pada pihak ketiga dapat menjadi obyek kesepakatan perdamaian oleh Penggugat dan Tergugat

Untuk mengetahui proses penyelesaian sengketa terhadap harta bersama yang dijadikan jaminan utang pada pihak ketiga.

\section{Metode}

Metode penelitian yang dipakai di dalam penulisan ini ialah metode normatif yaitu berdasarkan studi pustaka, menggunakan cara membaca, serta mengkaji dari materi yang 
dibahas dalam skripsi ini serta menggunakan bahan sekunder yang didapatkan dari beberapa media massa baik cetak maupun elektronik. Sedangkan pendekatan masalah yang digunakan secara yuridis yaitu dengan meninjau peraturan yang berhubungan dengan permasalahan.

Adapun sumber bahan hukum yang digunakan yaitu:

Sumber bahan hukum Primer, yakni : Undang-undang Nomor 4 tahun 1996 tentang Hak Tanggungan, HIR/RBG, Undang-undang Nomor 7 tahun 1989yang diubah dengan Undang-undang Nomor 3 tahun 2006 dan perubahan kedua dengan Undang-undang Nomor 50 tahun 2009 tentang Peradilan Agama, Peraturan Mahkamah Agung RI ( PERMA ) Nomor 1 Tahun 2016 tentang Prosedur Mediasi di Pengadilan

Sumber bahan hukum Sekunder, yakni: bahan-bahan hukum yang diperoleh dari meliputi buku-buku teks, jurnal hukum, dan komentar atas putusan pengadilan.

\section{Hasil Penelitian dan Pembahasan}

\section{Kedudukan Harta yang Sedang Dijadikan Utang dalam Hukum Jaminan}

Hukum Jaminan disebut juga dengan zekerheidsrechtten atau hak jaminan, yakni peraturan hukum yang mengatur tentang jaminan piutang seorang kreditor terhadap seorang debitur. Hukum Jaminan mengatur tentang jaminan piutang seseorang. Menurut J. Satrio, hukum jaminan itu diartikan peraturan hukum yang mengatur tentang jaminan-jaminan piutang seorang kreditur terhadap seorang debitur. Ringkasnya hukum jaminan adalah hukum yang mengatur tentang jaminan piutang seseorang (Satrio, 2007).

Menurut M. Bahsan, hukum jaminan merupakan himpunan ketentuan yang mengatur atau berkaitan dengan penjaminan dalam rangka utang piutang (pinjaman uang) yang terdapat dalam berbagai peraturan perundang-undangan yang berlaku saat ini (Bahsan, 2008). Pasal 1131 KUH Perdata menentukan bahwa segala kebendaan orang yang berutang, baik yang bergerak ataupun yang tidak bergerak, baik yang sudah ada maupun yang baru aka nada di kemudian hari menjadi tanggungan untuk segala perikatannya dengan seseorang. Ketentuan tersebut menunjukkan bahwa piutang kreditor menindih pada semua harta debitur tanpa terkecuali. Hukum jaminan di artikan sebagai peraturan hukum yang mengatur tentang jaminan hukum seseorang kreditor terhadap seorang debitur

Hukum jaminan dibagi dalam 3 bagian, yakni Jaminan Kebendaan Jaminan perorangan dan Jaminan Lainnya. Khusus tentang Jaminan Kebendaan, memberikanhak kepada kreditor untuk didahulukan atau dimudahkan dalam mengambil pelunasan atas piutang atas hasil penjualan benda tertentu milik debitur. Penekanan lagi dalamJaminan Kebendaan tersebut, adalah jika ada benda atau harta tertentu yang dipegang oleh kreditor dan atas harta tersebut diikat dengan perjanjian penjaminan khusus yang mengiringi perjanjian uang piutang, maka kreditor tersebut diberi hak yang lebih khusus dan lebih diutamakan kreditor lain dalam pelunasan utang debitur dari penjualan harta tersebut. Hak yang lebih diutamakan tersebut disebut dengan hak previlage, sebagai seorang kreditor preferen, sedangkan yang tidak terikat dengan perjanjian istimewa tersebut disebut dengan hak kongkuren.

Adanya hak tersebut, maka seorang kreditor mempunyai kedudukan istimewa sebagai berikut :

Mempunyai hubungan langsung dengan atau atas benda tertentu milik debitur.

\section{Dapat dipertahankan kepada siapa saja}

Mempunyai sifat droit de suite artinya hak tersebut mengikuti bendanya di tangan siapapun berada.

Benda atau harta berupa tanah serta bendalain yang berkaitan dengan tanah, dapat diikatkan sebagai jaminan dalam bentuk Jaminan Hak Tanggungan, sebagaimana diatur dalam Undang-undang Nomor 4 Tahun 1996, pada pasal 1 ayat 1 telah memberi penegasanan adanyahak previlage (diutamakan) sebagai kreditor preferen bagi pemegang jaminan hak tanggungan tersebut.

Atas prinsip di atas, maka ketika sebuah obyekberupa tanah serta benda lain yang berkaitan dengan tanah, baik berupa bangunan, tanaman ataupun lainnya yang lekat dengan tanah, diikatkan sebagai jaminan utang, maka ketika itu pula Hak Kebendaan atas obyek tersebut beralih kepada kreditor preferan sebagai pemegang hak previlage. Hak istimewa tersebut mengikat kepada siapa saja termasuk kepada majelis hakim manakala obyek tersebut menjadi sengketa dalam sebuah proses litigasi.

Majelis Hakim Pengadilan Agama Denpasar yang memeriksa perkara Nomor 147/ Pdt.G/ 2018/ PA Dps tidak mempertimbangkan kedudukan harta bersama yang dijadikan obyek 
sengketa sengketa, padahal sejak awal sudah didalilkan penggugat dalam positanya bahwa sebidang tanah dengan bangunan rumah tersebut adalah harta bersama perkawinan yang saat ini masih dalam penjaminan utang di bank yang dilakukan olehkedua belah pihak tersebut. Majelis hakim hanya terpaku pada ketentuan dalam Perma Nomor 1 Tahun 2016, bahwa bila kedua belah pihak berhasil mencapai perdamaian, dapat dituangkan dalam akta perdamaian sebagai penyelesaian sengketa.

Menurut penyusun, seharusnya majelishakim mengedepankan prinsip hukumjaminan, karena dengan dijadikannya obyek sengketa tersebut sebagai jaminan utang maka kepemilikan Penggugat dan Tergugat terhadap harta sebagaimana dimaksud tidaklah sempurna sebagai harta bersama hasil perkawinan mereka. Hak kebendaan terhadap harta tersebut dimiliki oleh pihak pemegang jaminan, dimana pemegang hak kebendaan tersebut berdasarkan ketentuan hukum, memegang hak previlage sebagai kreditor Preferen, yang harus diutamakan haknya atas harta yang dijadikan jaminan tersebut ;

Bahwa, atas keadaan yang demikian pula, maka penyusun berpendapat harta bersama perkawinan yang sedang dalam kedudukannya sebagai jaminan utang, tidak dapat dijadikan obyek sengketa kepemilikan, ataupun obyek dalam akta perdamaian antara penggugat dan tergugat tanpa melibatkan pihak pemegang hak jaminan. Seharusnya gugatan Penggugat tentang harta tersebut dianggap cacat formil dan harus dinyatakan tidak dapat diterima

\section{Penyelesaian Sengketa Terhadap Harta Ber- sama yang Sedang Dijadikan Jaminan Utang Pada Pihak Ketiga.}

Berdasarkan hasil penelitian di atas, terlihat bahwa proses dicapainya Akta Perdamaian adalah setelah para pihak melakukan mediasi, tercapai kesepakatan pihak perkara tentang pokok sengketa yang dirumuskan dalam perjanjian perdamaian. Pada sidang yang ditentukan, pihak perkara mengajukan perjanjian perdamaian tersebut agar dijadikan akta perdamaian sebagai penyelesaian sengketa mereka. Majelis Hakim kemudian bermusyawarah dan kemudian memutuskan perkara tersebut dalam Akta Perdamaian yang di dalamnya terdapat putusan dengan irah-iraheksekutorial, dengan penghukuman kepada pihak penggugat dan tergugat agar melaksanakan isi akta tersebut (Wayan \& Ketut, 2017).

Begitu sederhana proses tersebut, sehingga secara sekilas, proses tersebut telah memenuhi asas penyelesaian perkara yakni asas sederhana, cepat dan biaya ringan. Akan tetapi jika dicermati lebih dalam terdapat prinsip hukum yang tidak terpenuhi baik secara formil maupun materiil.

Secara materiil, Akta Perdamaian tersebut menyalahi ketentuan hukum jaminan atas barang tidak bergerak, sebagaimana telah diuraikan dalam pokok bahasan di atas. Adapun secara formil, penyusun dapat menguraikannya sebagai tersebut di bawah ini ;

Sebagaimana yang telah diketahui bersama, bahwa Mahkamah Agung telah mengeluarkan Perma Nomor 1 Tahun 2016 tentang Mediasi di Pengadilan, yang prinsip pokok dalam aturan tersebut adalah penegasan bahwa proses mediasi menjadi satu kesatuan yang tidak terpisahkan dengan acara perdamaian sebagaimana diatur dalam pasal 130 HIR dan 154 $\mathrm{RBg}$, dengan wilayah keberlakuan pada sengketa perdata di peradilan umum dan peradilan agama. Dengan demikian, maka ketentuan dalam Perma tersebut menjadi ketentuan hukum acara yang wajib dijalankan dalam memeriksa perkara perdata di peradilan umum dan peradilan agama, termasuk dalam sengketa harta bersama perkawinan.

Dalam perkara Nomor 147/ Pdt.G/ 2018/ PA Dps tersebut, majelis hakim mengesahkan kesepakatan perdamaian, pada hari sidang saat diajukan perjanjian tersebut, tanpa mempertimbangkan prinsip hukum jaminan dalam perkara dimaksud. Proses yang demikian sangatlah berbahaya dan rawan terjadinya penyelundupan hukum oleh pihak perkara yang purapurabersengketa untuk mencapai tujuan tertentu dengan cara melawan hukum. Hal tersebut karena subtansi dari akta perdamaian adalah kemauan hukum para pihak yang berperkara, yang kemudian dikukuhkan dengan kekuatan eksekutorial yang kekuatannya sama dengan putusan pengadilan. Hal yang disepakati ataupun yang dikehendaki oleh pihak perkara belum tentu memenuhi kebenaran prinsiphukum yang seharusnya didudukkan dalam hal yang disengketakan tersebut, atau dapat juga merugikan pihak ketiga. Sehinggasudah seharusnya majelis hakim tidak begitu saja menerima kesepakatan perdamaian menjadi Akta Perdamaian tanpa mempertimbangkan kebenaran isinya. Hal tersebut pula telah ditentukan dalam pasal 27 ayat 2 Perma Nomor 1 Tahun 2016.

Perma tersebut sebenarnya telah memberikan jalan sebagai tata cara dalam memutuskan perkara dengan akta perdamaian. Secara ringkas dapat penyusun paparkan, bahwa 
setelah para pihak mencapai kesepakatan damai dan menuangkannya dalam akta perdamaian dan mengajukannya kepada majelis hakim. Setelah menerima Kesepakatan Perdamaian tersebut Hakim Pemeriksa Perkara segera mempelajari dan menelitinya dalam waktu paling lama 2 (dua) hari. Jika belum memenuhi ketentuan hukum, maka dikembalikan Kesepakatan Perdamaian kepada Mediator dan Para Pihak disertai petunjuk tentang hal yang harus diperbaiki. Para Pihak dan/ atau mediator wajib mengajukan kembali Kesepakatan Perdamaian yang telah diperbaiki paling lama 7 (tujuh) hari, dan kemudian dalam waktu paling lama 3 (tiga)hari setelah menerima Kesepakatan Perdamaian yang diperbaiki,Hakim Pemeriksa Perkara menerbitkan penetapan hari sidang untuk membacakan Akta Perdamaian.

Proses yang demikian itu tidak terlewati dalam proses perkara, sehingga akta perdamaian yang telah ditetapkan dapat merugikan pihak ketiga, yakni pihak bank sebagai pemegang hak jaminan, yang secara hukum ( ex lege ) ia mempunyai hak previlage sebagai kreditor preferen yang harus diutamakan terhadap obyek sengketa tersebut.

Menurut pendapat penyusun, jika suami istri atau bekas suami istri bersengketa terhadap harta bersama yang dijadikan jaminan utang sebagaimana obyek penelitian ini, seharusnya mendudukkan pihak pemegang jaminan (bank) sebagai salah satu dari pihak perkara, karena sejak dijadikannya obyek tersebut sebagai jaminan, kepemilikan menjadi hak 3 pihak, yakni suami dan istri, sebagai pemilik awal tetapi pemilikan tersebut tidak penuh lagi karena adanya perjanjian penjaminan, serta bank sebagai pemilik hak kebendaan berupa hak previlage jaminan yang kedudukannya justru diutamakan. Dengan begitu, maka akan jelas duduk perkara tentang kedudukan harta tersebut, serta jelas pula berapa kewajiban penggugat dan tergugat terhadap pemegang hak jaminan tersebut, karena yang harus dibagi bukan hanya obyek rumah tersebut, juga tentunya harus jelas pembagian kewajiban bekas suami istri tersebut kepada bank pemegang jaminan dimaksud.

\section{Simpulan}

Bahwa, harta bersama perkawinanyang sedang dalam kedudukan sebagai jaminan utang, tidak dapat dijadikan obyek sengketa kepemilikan, ataupun obyek dalam akta perdamaian antara penggugat dan tergugat tanpa melibatkan pihak pemegang hak jaminan. Seharusnya gugatan perkara nomor 147/ Pdt.G/ 2018/ PA Dps dianggap cacat formil dan dinya- takan tidak dapat diterima.

Suami istri atau bekas suami istri bersengketa terhadap harta bersama yang dijadikan jaminan utang, harus mendudukkan pihak pemegang jaminan sebagai salah satu dari pihak perkara. Jika terjadi kesepakatan perdamaian yang kemudian dituangkan dalam Akta Perdamaian, haruslah dengan tata cara yang mengacu pada ketentuaan pasal 27 dan 28 Perma Nomor 1 Tahun 2016.

\section{Daftar Pustaka}

Artadi, I. K., \& Asmara, D. N. R. (2017). Anatomi Kontrak Berdasarkan Hukum Perjanjian. Denpasar: Udayana University Press.

Bahsan, M. (2008). Hukum Jaminan dan Jaminan Kredit Perbankan Indonesia. Jakarta: PT. Raja Grafindo Persada.

Hartanto, J. A. (2017). Hukum Harta Kekayaan Perkawinan. Jawa Timur: Laksbang pressindo.

Jamil, J. (2017). Hukum Materil Perkawinan di Indonesia. Jurnal Al-Qadau: Peradilan Dan Hukum Keluarga Islam, 4(2). Retrieved from http://journal.uinalauddin.ac.id/index.php/al-qadau/ article/view/5752

Satrio, J. (2007). Hukum Jaminan Hak Jaminan Kebendaan. Bandung: PT. Citra Aditya Bakti.

Wayan, W. I., \& Ketut, A. I. (2017). Penyelesaian Sengketa Di Luar Pengadilan. Denpasar: Udayana University Press. 